Discussion Paper No. 08-008

\title{
Are Local Milieus the Key to Innovation Performance?
}

Hanna L. Binz and Dirk Czarnitzki

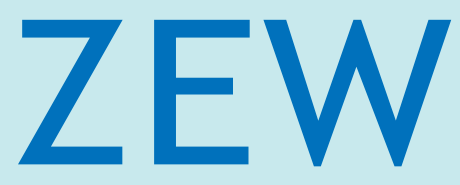

Zentrum für Europäische Wirtschaftsforschung $\mathrm{GmbH}$

Centre for European

Economic Research 
Discussion Paper No. 08-008

\title{
Are Local Milieus the Key to Innovation Performance?
}

\author{
Hanna L. Binz and Dirk Czarnitzki
}

First version: January 2008

Revised version: June 2008

Download this ZEW Discussion Paper from our ftp server:

ftp://ftp.zew.de/pub/zew-docs/dp/dp08008.pdf

\begin{abstract}
Die Discussion Papers dienen einer möglichst schnellen Verbreitung von neueren Forschungsarbeiten des ZEW. Die Beiträge liegen in alleiniger Verantwortung der Autoren und stellen nicht notwendigerweise die Meinung des ZEW dar.
\end{abstract}

Discussion Papers are intended to make results of ZEW research promptly available to other economists in order to encourage discussion and suggestions for revisions. The authors are solely responsible for the contents which do not necessarily represent the opinion of the ZEW. 


\section{Non-technical Summary}

Based on the general theory of location a new theory of economic geography, regional economic performance and growth has emerged. The focus of recent studies has shifted from analyzing performance of regions that varies because of naturally given resources towards analyzing factors affecting the development of regions. Besides, studies at the regional level, more recently, investigation has been further broken down to the firm level. Since the early days of location theory locational characteristics have been regarded as important for firm performance. However, it has also been argued that the importance of geographic proximity may decrease as industries become more knowledge intensive and as communication systems become highly sophisticated. Therefore, knowledge intensive activities such as innovation recently attracted more attention in this discussion. Yet, results from empirical studies aiming at providing a regional economics perspective on innovation performance, are often inconclusive or controversial. It appears challenging to identify regional factors driving innovation success at the firm level.

This study takes the approach of explaining success of firms in turning knowledge into marketable products by the firms' local innovation milieus. Thereby, we assume that agglomeration economies may play an important role for this transfer process. As suggested by the literature on regional innovation systems, some locational factors seem to be of special importance for firms' innovation activities. In particular, locational factors facilitating intended knowledge transfer and knowledge spillovers. Sources of knowledge spillovers may not only be universities and research institutions, but also qualified personnel in an industry, customers, suppliers or competitors, as well as collaboration partners that generate positive knowledge externalities.

Our objective is to identify the most important factors of the firms' local milieus for successful innovation activities. Further, we compare factors assumed to affect all firms uniformly to perception based factors as we assume that firms judge the attractiveness of locations by a heterogeneous set of criteria. This allows modeling of firms utilizing location factors to different extents.

We focus on firms in the region of Flanders, where survey data provide us with information on factors that were highly relevant for the firms' location decisions and well as information on their innovation performance. In addition, we use data at the regional level to construct regional indicators that may affect innovation performance. This allows comparing the two concepts of perceived location factors versus "real" geographical differences. 
By taking firms' awareness of their location milieu and thus their utilization of the respective factors into account, we are able to identify effects of local availability of highly skilled labor force as well as effects of the proximity to suppliers in the region. Our results also show that locational factors obtained from the survey provide more accurate explanation on how local milieus facilitate innovation than regional characteristics that are assumed to affect all firms uniformly. Our results illustrate that perception - reflecting awareness and utilization - is important for explaining organizational behavior and also applies to how regional characteristics affect innovation success. 


\section{Das Wichtigste in Kürze}

Im Zuge wachsender Bedeutung wissensbasierter Industrien in entwickelten Volkswirtschaften wandelt sich der Fokus regional-ökonomischer Studien. Während in klassischen Untersuchungen Unterschiede in regionalen Entwicklungen eher auf die Verteilung natürlicher Ressourcen zurückgeführt wurden, werden heutzutage andere Faktoren wie Regionalpolitik, Firmennetzwerke, Humankapital, Infrastruktur etc. für die Entwicklung von Regionen berücksichtigt. Eine besondere Rolle werden auch Innovationen für den regionalen technischen Fortschritt beigemessen. Darüber hinaus gewinnen neben Studien auf regionaler Ebene mikroökonomische Analysen auf der Firmenebene an Bedeutung.

In der Diskussion über die Rolle regionaler Charakteristika für die Leistungsfähigkeit von Unternehmen wurde in der Literatur argumentiert, dass die Relevanz lokaler Gegebenheiten für wissensintensive unternehmerische Aktivitäten - auch in Anbetracht fortschrittlicher Informations- und Kommunikationstechnologien - geringer werden könnte. Aus diesem Grund ist der Einfluss lokaler Milieus insbesondere auf den Erfolg wissensintensive Aktivitäten von großem Interesse. Insbesondere stehen Faktoren im Fokus, die Wissenstransfer oder Wissensspillovers fördern. Empirische Studien liefern jedoch häufig keine schlüssigen oder gar kontroverse Ergebnisse bei der Identifizierung bedeutender Regionalfaktoren, die den Innovationserfolg auf der Unternehmensebene begünstigen.

Diese Studie verfolgt einen neuen Ansatz zur Untersuchung regionaler Einflussfaktoren auf den unternehmerischen Innovationserfolg. Ziel dabei ist es, die wichtigsten Faktoren lokaler Innovationsmilieus für die erfolgreiche Markteinführung innovativer Produkte $\mathrm{zu}$ identifizieren. Dabei berücksichtigen wir, anders als in früheren Studien, dass lokale Gegebenheiten nicht alle Unternehmen gleichermaßen beeinflussen müssen.

Unternehmensdaten aus Flandern (Belgien) geben uns dabei Informationen über den Innovationserfolg und die lokalen Faktoren, die nach subjektiver Einschätzung von besonderer Bedeutung für diese Unternehmen im Hinblick auf ihre Innovationsaktivitäten sind. Die zusätzliche Untersuchung ,realer“ regionaler Indikatoren ermöglicht den Vergleich der Konzepte von wahrnehmungsbasierten und regionaldatenbasierten Einflüssen.

Unter Berücksichtung der individuellen Wahrnehmung und in Anspruchname regionaler Faktoren können in der Tat Effekte lokaler Milieus für wissensintensive Unternehmensaktivitäten, wie die geographische Nähe zu Zulieferern und die Verfügbarkeit hochqualifizierter Arbeitskräfte, identifiziert werden. Darüberhinaus zeigen wir, dass die auf Wahrnehmung basierenden Indikatoren größere Erklärungskraft hinsichtlich des Einflusses lokaler Milieus auf den Innovationserfolg haben als tatsächliche geografische Unterschiede, denen in regionalökonomischen Studien typischerweise die Annahme zugrunde liegt, dass sie die Leistung aller Unternehmen im gleichen Ausmaß beeinflussen. Unsere Ergebnisse verdeutlichen daher die Bedeutung wahrnehmungsbasierter Indikatoren für die Untersuchung von Einflüssen regionaler Faktoren auf Unternehmenserfolg. 


\title{
Are local milieus the key to innovation performance?
}

\author{
forthcoming in the Journal of Regional Science
}

\author{
Hanna L. Binz ${ }^{\mathrm{a}, \mathrm{b}, \mathrm{c}}$ and Dirk Czarnitzki ${ }^{\mathrm{a}, \mathrm{b}, \mathrm{c}}$ \\ a) K.U. Leuven, Dept. of Managerial Economics, Strategy and Innovation, Belgium \\ b) Steunpunt $O \& O$ Indicatoren at K.U.Leuven \\ c) Centre for European Economics Research (ZEW), Mannheim, Germany
}

This version: June 2008

\begin{abstract}
This study investigates how local milieus foster innovation success in firms. We complement the common practice of linking firm performance indicators to regional characteristics with survey evidence on the perceived importance of locational factors. While the former approach assumes that location characteristics affect all firms in the same way, the survey allows us to model how firms judge the attractiveness of locations using a heterogeneous set of criteria. It turns out that the availability of highly skilled labor and the proximity to suppliers matter for firms' innovation performance. Interestingly, location factors obtained from the survey provide a more accurate explanation of how local milieus facilitate innovation.
\end{abstract}

Keywords: $\quad$ Innovation performance, $R \& D$, location factors, Flanders JEL-Classification: $\mathrm{O} 31, \mathrm{O} 38$

Hanna L. Binz

K.U.Leuven

Dept. of Managerial Economics, Strategy and Innovation

Dekenstraat 2

3000 Leuven

Belgium

Phone: +32 16325793

Fax: +3216325799

E-Mail: hanna.binz@econ.kuleuven.be
Dirk Czarnitzki

K.U.Leuven

Dept. of Managerial Economics, Strategy and Innovation

Naamsestraat 69

3000 Leuven

Belgium

Phone: +32 16326906

Fax: + 3216326732

E-Mail: dirk.czarnitzki@econ.kuleuven.be

Acknowledgement: We thank the editor and two anonymous referees for very valuable comments. We are also grateful to IWT Flanders for providing their ICAROS database on public innovation subsidies. 


\section{INTRODUCTION}

Based on the general theory of location (e.g. Lösch, 1938), a new theory of economic geography, regional economic performance and growth has emerged (e.g. North, 1955, Shefer and Frenkel 1998, Acs 2000, Acs and Varga 2002, Fujita and Thisse 2000).

The focus of recent studies has shifted from analyzing how the performance of regions varies because of naturally occurring resources and the resulting comparative advantages in trade towards analyzing factors affecting the development of regions. Particular attention has been paid to the development of new technologies, products or services (see Kleinknecht and Poot 1992, Hassink 1993, Grossman and Helpman, 1990a,b, 1994). The main objective of this branch of research is to examine and understand locational factors that enable certain regions to develop better or faster than others.

Besides studies at the regional level, more recent research has focused on even smaller units, i.e. on the firm level. Since the early days of location theory, locational characteristics have been regarded as important for firm performance. However, it has also been argued that the importance of geographic proximity may decrease as industries develop towards being more knowledge intensive and as communication systems become highly sophisticated. Therefore, knowledge intensive activities such as innovation have recently attracted more attention in this discussion (Feldman 1994, Audretsch and Feldman 1996, Audretsch 1998, Feldman and Audretsch 1999).

Yet results from empirical studies aiming at a regional perspective on innovation performance are often inconclusive or controversial. It appears difficult to identify regional factors that drive innovation success at the firm level. For example, Love \& Roper (2001) find no effect from regional $R \& D$ intensity, $R \& D$ collaboration or industry employment on innovation activities for the UK and Ireland.

This study focuses on regional characteristics affecting the innovation performance of firms. Such factors external to the firm shape the 'local innovation milieu' (Shefer and Frenkel 1998) of firms and subsequently impact firms' innovation performance in a region.

As suggested by the literature on regional innovation systems, some locational factors seem to be of special importance for firms' innovation activities. In knowledge-based economies the crucial resource is knowledge that can be generated and transmitted within and across industries. Thus, locational factors which facilitate intentional knowledge transfer and 
knowledge spillovers may have a significant impact on firms' innovation performance. Potential sources of knowledge transfer include universities and research institutions, but also qualified personnel in an industry, customers, suppliers or competitors, as well as actual and potential collaboration partners that generate positive knowledge externalities for the R\&D department. Inter- or intra-industry-spillovers, information and human resource advantages may increase firms' innovation propensity in some regions. Furthermore, if these firms go on to innovate, these factors may make their innovation outcome more successful, which ultimately enhances regional economic growth.

This study takes the approach of explaining firms' success in turning knowledge into marketable products by the firms' local innovation milieus. We assume that agglomeration economies may play an important role in this transfer process. Our objective is to identify the most important factors in the firms' local milieus that contribute to successful innovation activities. We also compare factors assumed to affect all firms uniformly to perception based factors, as we assume that firms judge the attractiveness of locations by a heterogeneous set of criteria. This allows us to model the way firms utilize location factors to different extents.

We focus on firms in the region of Flanders, where survey data provide us with information on factors that were highly relevant for the firms' location decisions and well as information on their innovation performance. In addition, we use data at the regional level to construct regional indicators for factors that may affect innovation performance. This allows us to compare these indicators to the respective survey location factors of the perceived importance of those regional factors.

Section 2 of this article gives an overview of the literature, describes distinctive features of the region of Flanders and outlines the conceptual framework of this study. Section 3 describes our data and section 4 presents the econometric approach and estimation results. We conclude in section 5 .

\section{BACKGROUND AND CONCEPTUAL FRAMEWORK}

\section{Literature Review}

The allocation of production and industry in geographical clusters is not a recent phenomenon. Many examples for industries that are concentrated in space can easily be found. In the early days of location theory, in principle consisting of the work of Thünen, Weber, Lösch and some others, strong emphasis was placed on the role of transport cost - as 
the (most) important part of the relative cost of production - in shaping regional economic activities. In markets where the transportation of raw materials or goods is very costly, the location of industrial activity is pre-determined by the location of natural resources. Consequently, export opportunities resulting from comparative advantages in the geographic area shape economic activity in regions.

North (1955) analyzes regional economic growth based on the principles of location theory, combining location theory and theory of regional economic growth. Differences in production structure, spatial concentration of activity, and performance of regions were explained by underlying characteristics such as infrastructure, natural resources or the availability of labor.

A new theory of geography, locational economic performance and growth emerged, based on the general theory of location. While earlier studies aimed at explaining differences in growth between regions by differences in aggregated export activity, more recent contributions focus on determining which locational factors foster a region's economic success. Consequently, the focus shifted from analyzing conditions of regions that vary because of naturally occurring resources and the resulting comparative advantages in trade towards analyzing factors that affect the development of regions. The prevailing factors were found to be the development of new technologies, products and services. Recently, the performance of regions as a whole has not been the sole centre of interest.

The object of investigation has been further broken down to assessing the performance of firms or industries in a region given certain locational factors. Research in the field of regional economics has especially stressed the importance of locational factors, such as the availability of input factors like labor and capital, as well as the efficiency of transportation systems. Most recently, the efficiency of communication systems has been added to this list (see, for example, Shefer and Frenkel 1998, Acs 2000, Acs and Varga 2002, Fujita and Thisse 2000 or Ottaviano and Puga 1998 for a more extensive discussion of the literature).

The rather simple principles of the early contributions to location theory are called into question in times when intellectual property, human and financial capital are the most important input factors. Consequently, advances in communication technology and its role in the process of technological change and the diffusion of innovation have influenced the literature on the economics of location (for example Audretsch and Feldman 1996 or AutantBernard 2002). For some time it was argued that the importance of locational factors would decrease with the emergence of information and telecommunication technologies. Theoretical 
and empirical work has reacted to this preconception, arguing that the importance of local proximity is not declining, since global competition increases the value of knowledge-based economic activity (see, for example, Audretsch 1998, Basevi and Ottaviano 2002, or AutantBernard 2002 for a discussion). Knowledge as opposed to information may be generated and transmitted less efficiently over longer distances. Innovation success may therefore still be highly reliant on local factors (for example Baptista and Swann 1998, Cohen and Levinthal 1989). While marginal costs of transmitting information across geographic space have in fact significantly decreased, the marginal cost of transmitting knowledge, and especially tacit knowledge, still rises with distance (for example Audretsch 1998 and von Hippel 1994).

Stuart and Sorenson (2003), explaining firm co-location in high-technology industries, suggest that industries cluster because entrepreneurs may have difficulties accessing essential resources which they may seek to overcome by making use of social and professional ties. However, they find that locational factors that promote firm founding rates in a certain region may differ from those factors which are essential for firm performance in that region. Thus, analyzing firm performance, and how it is affected by different locational conditions, means analyzing the direct effects of locational determinants. This also includes incentives set by governmental policies, as well as investment incentives stemming from factors that are a result of given locational productivity drivers.

A variety of theoretical and empirical studies show the effects of agglomeration and localization economies on production efficiency (Shefer 1973, Richardson 1974 or Sveikauskas 1975, Harhoff 1999 and Rosenthal and Strange 2001). Agglomeration economies can be described as positive returns to scale at regional level, e.g. the advantage of locating in a particular area increases with the number of firms in the area. Agglomeration economies can come about when firms benefit from more specialized suppliers in areas with a higher industry concentration (Marshall 1920), or result from the existence of localized knowledge externalities (Jaffe et al. 1993, Ellison and Glaser 1999). ${ }^{1}$

The motivation for analyzing these questions lies in the relevance of such findings in the design of regional development policies aimed at fostering innovation in different regional settings. 
Strange et al. (2006) address the aspect of uncertainty-driven agglomeration. The need for skilled workers and technological innovativeness are prominent examples of such agglomeration forces. Interestingly, they find that the agglomeration force of technological innovativeness is associated with city size, while the need for skilled workers relates to industry clustering. Thus, firms facing uncertain needs for specialized labor skills benefit from agglomeration while technological uncertainty encourages agglomeration (see also Jaffe et al. 1993 and Audretsch and Feldman 1996). The authors use data from the 1999 Canadian Survey of Innovation. The survey provides information on firms' perceptions of their competitive environments and success factors. The authors' approach differs from existing agglomeration studies (such as Henderson et al. 1995, Henderson 2003, and Rigby and Essletzbichler 2002) in the way that they incorporate firm perception. However, none of these studies addresses firms' innovation performance.

The role of technological innovation and its positive impact on competitiveness, development and growth of regions has been of substantial interest in numerous articles (for example Davelaar and Nijkamp 1989, Feldman 1994a, Frenkel and Shefer 1997, Feldman and Kutay 1997, Davelaar and Nijkamp 1997, Ciccone and Hall 1996, Baptista and Swann 1998 and Porter 1998). Grossman and Helpman (1990a, and b, 1991, 1994) for example, state that regions with a high level of innovation grow faster than comparable regions with low innovation rates. Looking at the story from a firm perspective, the potential importance of a firm's locational environment for its innovation activities has increasingly attracted attention (for example Kleinknecht and Poot 1992, Hassink 1993). Roper et al. (2000) find no support for the hypothesis that industry concentration positively influences the innovation propensity of firms in the UK. However, they do find other significant factors such as industry R\&D intensity and firms' participation in inter-firm networks. Moreover, they find a positive impact of the share of regional employment in small firms on firms' innovation activity, indicating the importance of smaller firms for regional innovation performance.

A firm's rate of innovation is likely to be affected by internal factors such as its age, size, industry and its R\&D intensity, as well as by factors external to the firm. Shefer and Frenkel (1998) define the sum of external factors as the 'local innovation milieu'. These factors

\footnotetext{
${ }^{1}$ Rosenthal and Strange (2003a,b) provide an extensive overview on the literature on agglomeration economies. See Essletzbichler and Rigby (2007) for an overview of the literature on economic geography and the regional
} 
include the rate of local innovation and the degree of cooperation and collaboration among firms. They find that R\&D intensity and a skilled labor force have a significant positive effect on innovation propensity. Moreover, they find that young firms are more likely to innovate in high-tech industries, but not in low-tech industries. This indicates that the effects of agglomeration and localization on the degree of innovation are stronger in industries where knowledge is presumably more codified or even tacit. Love and Roper (2001a) extend these analyzes by considering the influence of locational factors on outsourcing decisions in the innovation process. However, they find little evidence that locational factors play a role in such outsourcing decisions. Feldman and Audretsch (1999) investigate the question of whether diversity or specialization of economic activities in a region better promotes innovation. They come to the conclusion that diversity across complementary industries, presumably gaining from inter-industry knowledge spillovers, best promotes innovation activity (see also Jacobs 1969).

Audretsch and Feldman (1996) emphasize that firms may consider the effectiveness of potential spillovers when deciding on a location, and that this may be especially important in industries where generation of new economic knowledge is of relatively high importance. This argumentation has also drawn attention to the presence of universities as a locational factor (for example Anselin et al. 1997, 2000, Feldman 1994b and Fischer and Varga 2003, Varga 2000, 2001 or Huffman and Quigley 2002).

Zucker et al. (1998) use data from the Californian biotechnology sector and find a positive impact of research universities on firms located nearby. They conclude that this results not (only) from general R\&D knowledge spillovers as suggested by "New Growth Theory", but particularly from collaboration and intentional knowledge transfer between scientists and industry. They point out that star scientists are not simply located geographically close to biotechnology clusters, but also frequently engage in such companies as founders, employees or consultants.

Audretsch et al. (2003) link locational choice, as a strategic firm decision, to knowledge externalities in general and spillovers from universities in particular. They conclude that geographic proximity may be important in accessing the human capital embodied in university graduates, who may serve as a spillover mechanism. Their results suggest that a

dimension of technological change from an evolutionary perspective. 
firm's locational proximity to a university affects the firm's performance, especially if the knowledge generated in the university is codified and specific. Their results also illustrate that geographic proximity to certain locational factors is a key element of firm strategy and that locational choice shapes firm performance, especially of young firms. Estimating innovation production functions for UK, German and Irish manufacturing plants, Love and Roper (2001b) find evidence that regional factors influence the efficiency with which R\&D activities are translated into successful innovation. Their analysis does not support the hypothesis that networking activities, $R \& D$ co-operation or agglomeration support innovation performance. However, they do find that intra-group links are important determinants of innovation success.

As the literature in the field of knowledge transmission and innovation points out, the choice of location for a firm's innovation activity may be of special importance for its innovation performance. Duranton and Puga (2001) theoretically and empirically analyze how innovative activities, in particular process innovations, are affected by the role of diversified urban environments. Their (French) data supports the idea that production moves from diversified to specialized locations over the product life cycle. This underlines the importance of industrial diversification in the early phase of any innovation activities.

Duranton and Puga (2001) show that firms' locations for innovative activities are subject to special requirements. They further illustrate how, if diversified and specialized urban areas coexist, the former type of cities serve as nurseries for the latter by providing a fertile experimentation environment. Although the authors conclude that neither diversification nor specialization alone can be identified as the 'best urban economic structure', their findings can be interpreted with respect to innovation performance as evidence that diversification is more likely to promote innovation performance, as it takes place in the early stages of the product life-cycle.

As well as being subject to variation over the product life-cycle, the perceived importance of certain locational characteristics may vary across firms and industries. Hellriegel and Slocum (1974) argue that perceptions are more important for explaining organizational behavior than objective conditions. Moreover, Meester (2000), for example, argues that "from a behavioral point of view, the willingness of entrepreneurs to move to a certain region is not depending on the real qualities of a region but on their perception, their image of those qualities". This aspect has so far been neglected in the literature on 'local innovation milieus'. In the following analysis we explicitly take this aspect into account. 


\section{The Region of Flanders and the History of its Innovation Policy}

The region of Flanders, located in the north of Belgium, exhibits special characteristics that make it a particularly interesting region in which to study the interaction of local milieus and innovation performance.

First, its advantageous geographical location in Northwest Europe and its regional characteristics distinguish it from other European regions. Flanders covers an area of 5,221 square miles $\left(13,522 \mathrm{~km}^{2}\right)$ and is one of the most densely populated areas in Europe, with 1,160 people per square mile $\left(455 / \mathrm{km}^{2}\right)$. Flanders is divided into five provinces (see table A3 in the appendix). Remarkably, these provinces are quite homogenous in terms of size, population density, physical infrastructure and number of universities. The region's attractiveness for foreign direct investment is also largely due to Flanders's geographical location in Europe (OECD 2005). Additionally, the harbor of the city of Antwerp is the largest harbor for non-containerized general cargo in Europe. According to the classification of international maritime traffic in 2005, the Port of Antwerp is the world's fifth largest harbor. Its location contributes to the attractiveness of the region for companies that distribute their goods throughout Europe. This is due to the fact that a large share of the European Union's purchasing power is located within a short distance (mainly Germany, United Kingdom, France and The Netherlands). Thus, the harbor ranks first in the 'centrality index for the ports of the Le Havre-Hamburg range'.

Second, besides these geographical traits, Flanders has demonstrated an increasing commitment towards fostering regional technological innovation over the past years, which has raised interest in researching in that field (Smits et al. 2006). The special focus on innovation policy is to be understood in the historical context of the region. In the sixties and early seventies, the region experienced exogenous growth, mainly through the arrival of multinational companies that chose Flanders because of its central location in Europe. At the time, governmental industrial policy concentrated on distributing the capital inflows among the Flemish provinces with the help of a subsidy and infrastructure policy (expansion legislation of 1959). In the later seventies and eighties, however, traditionally strong Belgian industries, such as the steel, coal, textile, and ship-building industries, started to decline. Economic policy responded defensively, trying to preserve employment by supporting these declining industries (Goorden 2004). Yet this approach was ineffective, because market conditions could not be altered by these measures. Thus, many companies were closed in spite of government subsidies (see for example Coucke and Sleuwaegen 2008). 
This experience showed that there was a need for an offensive strategy directed towards structural innovation in the sense of new products, new markets, and new production methods to prevent further economic decline in the region.

In 1981 the Flemish government separated itself from the national government and obtained specific powers in the area of regional economic policy. This separation facilitated the introduction of a new Flemish innovation policy. In 1989, most of the powers relating to science and technology policy were transferred to the Flemish government (until 1989, subsidies for research and development had remained federal). The new focus was explicitly emphasized in the 'DIRV Action, Vision of a Renewed Flemish Industrial Policy' document, that was submitted in November 1983 and is the basis of today's innovation policy in Flanders (Goorden 2004).

Further, in the nineties, a cluster policy was initiated to stimulate endogenous growth in Flanders. This cluster policy aimed to encourage trans-sectoral platforms and cooperation among companies. This would mean a considerable break from the past, as the industrial landscape of the Flemish region was traditionally characterized by isolated companies and branches of multinationals. Firms followed their own corporate restructuring strategies and local firms had no tradition of cooperation. In 1999 the so-called 'Innovation Decree' provided a legal framework to expand research and development policy to a broader, more integrated innovation policy (Goorden 2004).

Overall, Flanders's historically based focus on promoting knowledge intensive industries and technological innovation, its autonomy in innovation policy, in combination with its geographical characteristics and delineation, make it an interesting region in which to study the impacts of the local innovation milieu on firms' innovation performance.

\section{Conceptual Framework}

While most of the literature focuses on regional characteristics and regional development, fewer studies consider how regional factors shape firm-level behavior. Of course, firm performance is driven to a large extent by internal conditions, such as factors of production and their efficient combination. However, the literature has shown that factor use at the firm level depends to a certain extent on regional resource endowment. Our study combines scholarly research on the importance of regional milieus with innovation performance at the firm level, as innovation is often seen as key determinant for long-term economic growth and 
employment. As one of the few existing studies, Love and Roper (2001b) investigate how innovation at the firm level is linked to regional factor resources.

We extend this research in two dimensions. Love and Roper employ several regional variables, such as networking, $\mathrm{R} \& \mathrm{D}$ collaboration, agglomeration and intra-group spillovers, which may determine innovation performance. However, we hypothesize that conditional on a firm's specific resource requirements, the perceived importance of single elements of the portfolio of locational endowments in a region varies. Therefore, it may not be sufficient to link firm performance broadly to geographic characteristics. Consequently, we argue that location factors may have important consequences for the innovation performance of firms, but that these factors may not equally important for all firms.

Thus, in line with findings in new economic geography, we hypothesize that the local innovation milieu affects firm $i$ 's innovation performance in a way that

innovation performance ${ }_{i}=$

$f\left(\right.$ firm characteristics $_{i}$, survey factors $_{i}$, regional indicators $)$

We consider six different variables, highlighting heterogeneity in the firm specific importance of such characteristics in a firm's vicinity. In our survey data, firms indicated the importance of factors such as the availability of skilled labor $^{2}$, the vicinity of suppliers ${ }^{3}$, the presence of universities, local fiscal incentives, the quality of infrastructure and existing firm clusters for networking. The survey questions explicitly focus on the relevance of locational factors with respect to innovation capabilities. In addition to the survey factors, we also construct regional indicators from other data sources as counterparts that allow us to compare the effects of our survey indicators with the respective regional-level variables (see following section).

\section{DATA}

The data base for our analysis is the Flemish part of the Fourth Community Innovation Survey (CIS). It was carried out by the Steunpunt O\&O Indicatoren at KU Leuven in 2005,

\footnotetext{
${ }^{2}$ The relationship of worker skills, agglomeration and wage effects has recently been investigated by Bacolod et al. (2007) in greater detail (see also Glaeser 1999).

${ }^{3}$ Helsley and Strange (2002) show in a theoretical framework how important a network of input suppliers is for innovation as it reduces cost of innovating.
} 
collecting data for the time period 2002 to 2004. The database contains information on a cross-section of firms active in the manufacturing sector and in selected business services, collected from a representative sample of these sectors in the Flemish economy. ${ }^{4}$ The final sample includes 1,265 observations. We complement this database with information from the BELFIRST database on the population of Flemish firms. This allows us to construct indicators approximating regional industry diversification and industry employment. Moreover, we use the earlier CIS III survey for measuring $R \& D$ intensity and $R \& D$ collaboration in a region in our period of interest. We draw information on governmental and EU innovation subsidies on the regional level from the ICAROS database.

\section{Variable Description}

Our dependent variable, the measure of innovation performance, is the share of total sales due to new products (NEWSALES). ${ }^{5}$ New products are either market novelties or products that are new to the firm, but were on the market beforehand. As outlined in the previous section, we argue that location factors may have important consequences for the innovation performance of firms. Moreover, we suggest that these factors may not be equally important for all firms. Therefore, we consider six different survey-based variables that account for this fact. The CIS IV survey asked respondents to indicate the importance of following location characteristics for their innovation activities:

- the availability of skilled personnel (SKILL),

- the presence of a university $(U N I)$,

- $\quad$ the presence of main suppliers (SUPPLY),

- the presence of a relevant cluster of firms for networking (NET)

- the infrastructure (INFRA),

- $\quad$ the presence of local fiscal incentives (FIS).

Originally these variables were surveyed as ordinal variables on a 3-point scale (very important, some importance, not important). We use a set of six dummy variables that indicate whether the respondent firm evaluated the corresponding characteristic as very important.

\footnotetext{
${ }^{4} \mathrm{~A}$ detailed survey description can be found in Czarnitzki (2006).

${ }^{5} \mathrm{New}$ products are defined in concordance with the guidelines in the OSLO-Manual (OECD/Eurostat, 2005).
} 
Additionally, we include a number of regional characteristics that allow us to compare the effects of our six survey indicators to their regional-level counterparts. In particular, we use the regional employment in a firm's industry (INDEMP) as measure for skilled labor supply in the area. We calculated INDEMP based on the population of firms in Flanders, as the average number of employees in a region per sector. Industries are determined by 2-digit $\mathrm{NACE}^{6}$ codes and we divided Flanders into regions by 2-digit zip codes. Moreover, we calculate the industry diversification (DIVERS) in a firm's region based on 2-digit zip codes as the Herfindahl index of employment concentration across NACE 2-digit industries. This models the region's specialization, which proxies the firms' network of suppliers in the region. Thus, the most diversified regions would achieve an index close to zero, while more specialized industry landscapes in a region show higher values of DIVERS. Both measures, INDEMP and DIVERS, are conventionally used in urban economics to measure agglomeration.

Furthermore, we calculate the regions' shares of total government and EU R\&D-subsidies granted in the pre-sample period 1999-2001 (REGSUBS). As a counterpart for the survey factor $U N I$, we create a dummy variable indicating whether firms are located close to a university on a 2-digit zip code level (UNICLOSE).

The percentage of firms in the region that engaged in innovation collaborations in the past $(C O R E G)$ is taken into our analysis to model a counterpart to networking activities. In addition, we employ the regions' innovation intensity (defined by ZIP-codes) in the past to account for overall innovativeness (INNOREG). Both INNOREG and COREG are constructed using data from the third CIS survey, i.e. data corresponding to the year 2000 .

Using the survey factors, we are able to explicitly model the firms' awareness of regional characteristics. This means that we are not merely reliant on correlations of regional characteristics and performance indicators. In addition, we are able to compare the two measurement concepts. It should be noted that our survey factors and regional variables are not perfect pairs and must therefore be understood as best-available proxies given our data. However, we expect the data to be sufficient to compare the different concepts of regional indicators.

\footnotetext{
${ }^{6} \mathrm{NACE}$ is the European standard industry classification.
} 
As firm-level control variables, we consider the most important factors for innovation activity: innovation intensity is measured as total innovation expenditure divided by total sales (INNOINT). Total innovation expenditure is defined according to the Oslo Manual (OECD/Eurostat, 2005), and comprises intramural R\&D expenditure, extramural R\&D expenditure, the acquisition of machinery in combination with innovation projects, the acquisition of other external knowledge such as licenses, expenditure for training in combination with innovation projects, and market introduction costs for new products. Furthermore, we include capital intensity (KAPINT), measured as total physical assets per employee, because more capital-intensive firms are usually expected to be more innovative than labor-intensive firms. Referring to Love and Roper (2001b), we use a dummy variable indicating whether the firm is associated with a group (GROUP) to model intra-firm spillovers, which may be crucial for innovation success. We also use firm size, measured as the number of employees, as a control variable. Due to the skewness of the distribution the variable enters in log-linear form: $\ln (E M P)$. Note that we also tested non-log-linear relationships, but they turned out to be insignificant in all specifications. Finally, nine industry dummies are included to model heterogeneous innovation patterns across industries (see table A1 in the appendix).

\section{Timing of Control Variables}

In order to avoid a simultaneity bias in our regressions we use lagged values whenever possible. The dependent variable taken from the CIS IV is measured in the year 2004. We are able to lag the firm level controls EMP and KAPINT by two years, as the CIS IV collected data for the time period 2002-2004. It is not possible to lag the innovation intensity, though. This is only available for the year 2004. Due to possible feedback effects from product market success to investment, we instrument INNOINT with three dummy variables. We use three dummy variables measured at the firm level, namely indicators for the receipt of $R \& D$ subsidies during 2002 to 2004 from he Flemish government (FUNFG), the national government $(F U N N G)$, or the European Union (FUNEU). R\&D subsidies will affect the innovation investment of a firm directly, but cannot have a direct effect on product market success as this is a function of the actual level of investment and its outcome. Age is, of course, not lagged. We consider that as exogenous. Furthermore, the group indicator and the survey factors are time-invariant in the survey, as the CIS collects such information on a cross-sectional basis. 
For the regional characteristics, we can use deeper lags as they are obtained from other sources. COREG and INNOREG were calculated from the CIS III conducted in 2001, and therefore correspond to the year 2000. REGSUBS were obtained from the ICAROS database and cover the CIS IV pre-sample period, i.e. 1999-2001. INDEMP and DIVERS were calculated from the BELFIRST database where we can account for longer lags. We used the average values of the time period 1994-2001. Thus, we allow for a sufficient time lag so that knowledge capital due to a region's industry composition may induce spill-over effects that benefit a firm's production process. The variable UNICLOSE is time constant, as there were no recent foundations of universities.

Table 1 presents descriptive statistics of the variables used in the model. On average firms in our sample achieve $8.2 \%$ of total sales with products introduced to the market between 2002 and 2004. Average firm size amounts to 96 employees. However, $75 \%$ of firms in our sample have less than 68 employees (median employment equals 27). Average innovation intensity is about $2.9 \%$ and roughly $44 \%$ of firms are part of a group. The descriptive statistics of our location decision variables already show that the perceived importance of factors differs substantially. For instance the availability of qualified personnel (16\%) or infrastructure $(12 \%)$ in the region as well as the proximity to suppliers (14\%) are regarded as far more important than being located closely to an university $(4 \%)$, fiscal incentives $(8 \%)$ or the possibility for networking ( $8 \%$ ). On average, $22 \%$ of the firms in a region were engaged in R\&D collaboration in the year 2000 as indicated in the CIS III survey. About $24 \%$ of the firms in our sample are located close to university on a 2-digit zip code level (see appendix table A3). 
Table 1: Descriptive Statistics (1,265 observations)

\begin{tabular}{|c|c|c|c|c|c|}
\hline Variable & Unit & Mean & Std. Dev. & Min. & Max. \\
\hline \multicolumn{6}{|c|}{ Dependent variable } \\
\hline NEWSALES 2004 & in $\%$ of total sales & 8.231 & 17.996 & 0 & 100 \\
\hline NEWMARKET 2004 & in $\%$ of total sales & 3.766 & 10.999 & 0 & 100 \\
\hline \multicolumn{6}{|l|}{ Firm level controls } \\
\hline$E M P_{2002}$ & head counts & 95.970 & 274.608 & 1 & 5820 \\
\hline INNOINT $_{2004}$ & in $\%$ of total sales & 2.907 & 8.050 & 0 & 65.161 \\
\hline KAPINT $_{2002}$ & $\begin{array}{l}\text { (fixed assets in thousand } \\
\text { EUR)/EMP }\end{array}$ & 32.279 & 43.200 & 0.327 & 376.143 \\
\hline$G R O U P_{2004}$ & dummy & 0.443 & 0.497 & 0 & \\
\hline$A G E_{2004}$ & years & 28.310 & 23.927 & 1 & 169 \\
\hline \multicolumn{6}{|c|}{ Location factors obtained from survey } \\
\hline SKILL & dummy & 0.164 & 0.370 & 0 & \\
\hline$U N I$ & dummy & 0.039 & 0.193 & 0 & 1 \\
\hline$S U P P L Y$ & dummy & 0.144 & 0.351 & 0 & 1 \\
\hline INFRA & dummy & 0.117 & 0.322 & 0 & \\
\hline FIS & dummy & 0.067 & 0.250 & 0 & \\
\hline$N E T$ & dummy & 0.031 & 0.173 & 0 & \\
\hline \multicolumn{6}{|c|}{ Regional characteristics constructed from other data sources } \\
\hline$I_{I N D E M P_{1994-2001}}$ & $\begin{array}{l}\text { \# of employees in a firm's industry } \\
\text { in the region (in thousands) }\end{array}$ & 2.065 & 2.934 & 0.002 & 20.730 \\
\hline DIVERS $_{1994-2001}$ & $\begin{array}{l}\text { Herfindahl index of regional } \\
\text { industry concentration measured } \\
\text { by employment }\end{array}$ & 0.087 & 0.023 & 0.060 & 0.310 \\
\hline INNOREG $G_{2000}$ & innovation intensity per region & 0.062 & 0.035 & 0.009 & 0.263 \\
\hline$C O R E G_{2000}$ & $\begin{array}{l}\% \text { of firms engaged in } \mathrm{R} \& \mathrm{D} \\
\text { collaboration per region }\end{array}$ & 0.217 & 0.093 & 0 & 0.667 \\
\hline UNICLOSE & dummy & 0.241 & 0.427 & 0 & 1 \\
\hline$R E G S U B S_{1999-2001}$ & $\begin{array}{l}\text { regions share of total government } \\
\text { and EU R\&D subsidies granted in } \\
\text { the pre-sample period }\end{array}$ & 0.035 & 0.046 & 0 & 0.156 \\
\hline \multicolumn{6}{|l|}{ Instruments } \\
\hline$\overline{F U N F G_{2002-2004}}$ & $\begin{array}{l}\text { dummy for R\&D subsidy receipt } \\
\text { from Flemish government }\end{array}$ & 0.092 & 0.289 & 0 & \\
\hline$F U N N G_{2002-2004}$ & $\begin{array}{l}\text { dummy for R\&D subsidy receipt } \\
\text { from national government }\end{array}$ & 0.053 & 0.224 & 0 & \\
\hline$F U N E U_{2002-2004}$ & $\begin{array}{l}\text { dummy for R\&D subsidy receipt } \\
\text { from the European Union }\end{array}$ & 0.026 & 0.159 & 0 & 1 \\
\hline
\end{tabular}

Note: 9 industry dummies omitted. 


\section{ECONOMETRIC ANALYSIS}

We estimate Tobit models on innovation performance, because not every firm in our sample has a positive share of sales with new products, that is, NEWSALES is left censored. The model to be estimated can be written as

$$
N E W S A L E S^{*}=X^{\prime} \beta+\varepsilon,
$$

where NEWSALES* is the unobserved latent variable. The observed dependent variable is equal to

$$
N E W S A L E S=\left\{\begin{array}{l}
N E W S A L E S * \text { if } X^{\prime} \beta+\varepsilon>0 \\
0 \text { otherwise }
\end{array} .\right.
$$

$X$ represents the matrix of regressors, $\beta$ the parameters to be estimated, and $\varepsilon$ the random error term. The equation to be estimated is

$$
\begin{aligned}
& E\left(N E W S A L E S_{2004} *\right)=\beta_{0}+\beta_{1} \ln \left(E_{2002}\right)+\beta_{2} I_{2 N O I N T_{2004}}+\beta_{3} \text { KAPINT }_{2002}+\beta_{5} G R O U P_{2002-2004} \\
& +\beta_{6} \ln \left(A G E_{2004}\right)+\beta_{7} I N D E M P_{1994-2001}+\beta_{8} D_{I V E R S} S_{1994-2001}+\beta_{9} R D R E G_{2000} \\
& +\beta_{10} \text { COREG }_{2000}+\beta_{11} U N I C L O S E+\beta_{12} \text { REGSUBS }_{1999-2001}+\sum_{k=13}^{18} \beta_{k} L_{\text {OOC }}+\sum_{s=19}^{28} \beta_{s} S E C T O R_{s}
\end{aligned}
$$

where $L O C_{k}$ refer to our six location factors obtained from the survey and $S E C T O R_{s}$ to the 9 industry dummies. The standard Tobit model requires the assumption of homoscedasticity; otherwise the estimates are inconsistent (cf. Greene, 2005). We conducted several tests on heteroscedasticity (Wald tests and LR Tests) using a heteroscedastic specification of the Tobit model, in which we replaced the homoscedastic standard error $\sigma$ with $\sigma_{i}=\sigma \exp \left(Z^{\prime} \alpha\right)$ in the likelihood function. We included size class dummies based on the number of employees and industry dummies to model group-wise multiplicative heteroscedasticity. The tests find evidence of heteroscedasticity. We therefore only present the estimation results obtained from our heteroscedastic-consistent estimations.

As most explanatory variables are lagged, we can treat these as predetermined, that is, we avoid direct simultaneity between our dependent and the explanatory variables. The only problem arises for the innovation intensity. Unfortunately, we cannot lag it with the data at hand. Therefore, we instrument this variable to avoid a simultaneous equation bias. As 
instruments we consider innovation subsidies (FUNFG, FUNNG, FUNEU), as these should determine the innovation intensity of a firm positively. However, the subsidies should not have a direct effect on the share of sales with new products. Instead, subsidies influence investment in innovation projects, and then innovation efforts will affect the market outcome as measured by new product sales. We implement the IV estimation as a Full Information Maximum Likelihood estimator, where two equations are estimated simultaneously. The main equation is the new product sales equation as shown above. In addition, innovation intensity is regressed on all explanatory variables and the instruments. Wald-tests in the IV-Tobit model do indeed reject the possibility that the innovation intensity is exogenous. See Wooldridge (2002: 530-533) for details on the IV Tobit model.

Our estimations take into account a possible correlation of error terms within regions by computing regionally clustered standard errors.

Table 2 presents the regression results of six specifications: First, we display three heteroscedastic Tobit models where the innovation intensity is considered as exogenous. One model represents the full specification using both the perceived location factors and the "real" regional characteristics. As a robustness check, we then present two models where we omitted the perceived factors in one of the models, and the real characteristics in the other. Besides interpreting the sign of the coefficients and their significance levels, we are interested in which kind of location factors have higher explanatory power with respect to the firm-level performance. For this, we conduct a Wald-test on the joint significance of the regional variables. The other three specifications are analogous to the former, but now we account for the potential endogeneity of INNOINT using the IV-Tobit models.

Turning to the results, we find that the "real" regional characteristics are individually and jointly insignificant in all regressions. This basically coincides with the weak performance of such variables in previous studies. The perceived location factors, however, are jointly highly significant in all models. As the results show, the presence of skilled labor and the vicinity of suppliers have a positive effect on the innovation performance of firms. Further, we find a positive impact of networking and the availability of physical infrastructure, although these effects are weaker as they are not robust across all models. Note that in the IV Tobit all three indicators describing innovation subsidies positively affect innovation intensity. While we do not present the first stage regression in detail, we show a test on joint significance of the three instrumental variables in the bottom of the table. Those indicate that the instruments are 
highly significant in explaining INNOINT in all models. Consequently, we argue that none of the IV regressions suffers from a possible weak instruments problem.

With respect to innovation performance, our results illustrate that perceived factors seem to capture effects from the local innovation milieu better than general characteristics calculated at the regional level. We would like to point out that this may be because a regression analysis restricts the effect of regional characteristics in the sense that all variables affect the firms in the same region by the same magnitude. The perceived location factors, however, allow us to model the possibility that firms within a region may rely on a heterogeneous set of characteristics, as survey respondents rate only a selection of all factors as important.

The control variables show the expected effects. Consistent with findings in the literature, firm size and capital intensity have a positive effect on innovation performance. Additionally, the innovation intensity is naturally an important determinant for innovation outcome. For firms' age, we also find indications of a positive influence on innovation performance. This is confirmed in the IV models where all firm-level control variables remain positively significant. In line with findings of Love and Roper (2001b), it turns out that intra-firm spillovers as modeled by the GROUP variable are a source of important advantages for innovation.

\section{Robustness Checks}

Instead of NEWSALES, we also use a stricter definition of innovation performance, that is, success in introducing a market novelty. Analogously to our firm dependent variable, this is measured as the share of sales achieved with market novelties. New product sales include products that were already on the market, in which case the firm in question is imitating an existing product, i.e. a new product may just be new to the firm but not to the market. The variable NEWMARKET, however, accounts only for true market novelties, which may be considered as more radical or original innovations. It excludes the mere imitation of products.

Table 3 shows the regression results. Basically, we come to the same conclusions as in our less strict NEWSALES-model. In the full model specification the perceived location factors from the survey are jointly significant, while the "real" regional characteristics have no joint impact on the sales with market novelties. When we look at the individual impact we also find that the presence of skilled labor and the vicinity of suppliers matter. The availability of physical infrastructure is weakly significant in the standard Tobit model. Interestingly, however, we find that the region's innovation intensity is positively significant in the 
regressions. This is the only computed regional characteristic for which we find a positive effect on firms' innovation performance that is significant at the 5\% level. It seems that the regional endowment with $R \& D$ capital matters for more radical innovations, as firms may absorb cutting-edge knowledge for introducing market novelties. In contrast, there was no such effect when all innovations were considered in the previous NEWSALES regressions.

It should also be noted that the real regional characteristics are weakly jointly significant in the regression where the perceived factors are excluded. In the fully specified models, however, the perceived factors render the "conventional" characteristics jointly insignificant. 
Table 2: Heteroscedastic Tobit and IV Tobit on NEWSALES (1,265 observations)

\begin{tabular}{|c|c|c|c|c|c|c|}
\hline \multirow[b]{2}{*}{ Variable } & \multicolumn{3}{|c|}{ Heteroscedastic Tobit } & \multicolumn{3}{|c|}{ Heteroscedastic IV Tobit $^{+}$} \\
\hline & Full Model & $\begin{array}{c}\begin{array}{c}\text { Regional Indicators } \\
\text { only }\end{array} \\
\end{array}$ & $\begin{array}{c}\text { Survey Factors } \\
\text { only }\end{array}$ & Full Model & $\begin{array}{c}\text { Regional } \\
\text { Indicators only }\end{array}$ & Survey Factors only \\
\hline \multirow{2}{*}{ INNOINT $_{2004}$} & $1.158 * * *$ & $1.539 * * *$ & $1.178^{* * *}$ & $4.658 * * *$ & $5.186^{* * *}$ & $4.664 * * *$ \\
\hline & $(0.157)$ & $(0.169)$ & $(0.155)$ & $(1.273)$ & $(0.999)$ & $(1.264)$ \\
\hline \multirow{2}{*}{$\ln (E M P)_{2002}$} & $3.715 * *$ & $4.713 * * *$ & $3.658 * *$ & $2.944 *$ & $3.685 * *$ & $2.933 * *$ \\
\hline & $(1.651)$ & $(1.630)$ & $(1.597)$ & $(1.528)$ & $(1.462)$ & $(1.497)$ \\
\hline \multirow[t]{2}{*}{$K A P I N T_{2002}$} & $0.067 * *$ & $0.075 * *$ & $0.068 * *$ & $0.068 * *$ & $0.071 * *$ & $0.067 * *$ \\
\hline & $(0.033)$ & $(0.033)$ & $(0.0833)$ & $(0.031)$ & $(0.033)$ & $(0.066)$ \\
\hline \multirow[t]{2}{*}{$A G E_{2004}$} & $3.289 *$ & $3.387 *$ & $3.209 *$ & $3.983 * *$ & $3.977 * *$ & $0.031 * *$ \\
\hline & $(1.844)$ & $(1.860)$ & $(1.835)$ & $(1.899)$ & $(1.940)$ & $(1.838)$ \\
\hline \multirow[t]{2}{*}{$G R O U P_{2004}$} & $7.922 * * *$ & $9.458 * * *$ & $7.873 * * *$ & $6.794 * *$ & $7.452 * *$ & $7.026 * *$ \\
\hline & $(3.024)$ & $(3.220)$ & $(3.006)$ & $(3.187)$ & $(7.359)$ & $(3.106)$ \\
\hline \multicolumn{7}{|c|}{ Regional Indicators: } \\
\hline \multirow[t]{2}{*}{ INDEMP $_{1994-2001}$} & 0.233 & 0.090 & & 0.570 & 0.426 & \\
\hline & $(0.381)$ & $(0.484)$ & & $(0.520)$ & $(0.591)$ & \\
\hline \multirow[t]{2}{*}{ DIVERS $_{1994-2001}$} & -87.182 & -61.783 & & -42.012 & -20.889 & \\
\hline & $(56.171)$ & $(50.425)$ & & $(56.822)$ & $(55.176)$ & \\
\hline \multirow[t]{2}{*}{$I_{N N O R E G_{2000}}$} & 0.782 & 5.048 & & 2.453 & 1.407 & \\
\hline & $(31.648)$ & $(30.777)$ & & $(36.713)$ & $(37.068)$ & \\
\hline \multirow[t]{2}{*}{$C O R E G_{2000}$} & -16.684 & -13.416 & & -16.080 & -11.370 & \\
\hline & $(12.857)$ & (12.299) & & $(14.376)$ & $(13.453)$ & \\
\hline \multirow[t]{2}{*}{ UNICLOSE } & 0.131 & -2.268 & & -1.219 & -4.413 & \\
\hline & $(4.735)$ & $(4.253)$ & & $(4.54)$ & $(4.024)$ & \\
\hline \multirow[t]{2}{*}{ REGSUBS ${ }_{1999-2001}$} & 24.114 & 47.136 & & 18.474 & 48.885 & \\
\hline & (39.229) & $(43.872)$ & & $(36.155)$ & $(39.425)$ & \\
\hline
\end{tabular}




\section{Table 2 continued}

\begin{tabular}{|c|c|c|c|c|c|c|}
\hline \multicolumn{7}{|l|}{ Survey Indicators: } \\
\hline \multirow[t]{2}{*}{ SKILL } & $17.404 * * *$ & & $17.646^{* * *}$ & $13.099 * * *$ & & $13.264 * * *$ \\
\hline & $(3.017)$ & & $(3.051)$ & $(3.665)$ & & $(3.586)$ \\
\hline \multirow[t]{2}{*}{$U N I$} & 9.344 & & 8.724 & 0.696 & & 0.067 \\
\hline & $(6.308)$ & & $(6.348)$ & $(6.623)$ & & $(6.730)$ \\
\hline \multirow[t]{2}{*}{ SUPPLY } & $13.786 * * *$ & & $13.867 * * *$ & $12.058 * * *$ & & $12.437 * * *$ \\
\hline & $(2.431)$ & & $(2.431)$ & $(3.152)$ & & $(3.338)$ \\
\hline \multirow[t]{2}{*}{ INFRA } & $9.410 *$ & & $9.184 *$ & 3.827 & & 3.573 \\
\hline & $(5.268)$ & & $(5.097)$ & $(6.312)$ & & $(6.220)$ \\
\hline \multirow[t]{2}{*}{ FIS } & 1.036 & & 1.259 & 3.464 & & 3.087 \\
\hline & $(4.301)$ & & $(4.188)$ & $(5.365)$ & & $(5.287)$ \\
\hline \multirow[t]{2}{*}{$N E T$} & $11.735 * *$ & & $10.865^{*}$ & 3.932 & & 3.528 \\
\hline & $(5.567)$ & & $(5.689)$ & $(6.796)$ & & $(7.003)$ \\
\hline Intercept & $\begin{array}{l}-41.242 * * * \\
(9.423)\end{array}$ & $\begin{array}{l}-43.844 * * * \\
(10.476)\end{array}$ & $\begin{array}{l}-50.163 * * * \\
(9.762)\end{array}$ & $\begin{array}{l}-50.875^{* * *} \\
(11.619)\end{array}$ & $\begin{array}{l}-53.007 * * * \\
(12.136)\end{array}$ & $\begin{array}{l}-55.718 * * * \\
(10.741)\end{array}$ \\
\hline $\begin{array}{l}\text { Test of joint significance of } R E G I O N A L \\
\text { INDICATORS, } \chi^{2}(6)\end{array}$ & 5.32 & 4.04 & & 4.48 & 3.66 & \\
\hline $\begin{array}{l}\text { Test of joint significance of SURVEY } \\
\text { FACTORS, } \chi^{2}(6)\end{array}$ & $88.62 * * *$ & & $89.96^{* * *}$ & $33.30 * * *$ & & $32.45 * * *$ \\
\hline $\begin{array}{l}\text { Test of joint significance of SECTOR } \\
\text { dummies, } \chi^{2}(8)\end{array}$ & $38.61 * * *$ & $41.98 * * *$ & $35.24 * * *$ & $57.66 * * *$ & $51.96 * * *$ & $58.01 * * *$ \\
\hline Test on heteroskedasticity & $24.26 * * *$ & $36.70 * * *$ & $24.14 * *$ & $1,714.53 * * *$ & $1,758.13 * * *$ & $1,838.36^{* * *}$ \\
\hline Wald test of exogeneity & & & & $8.88 * * *$ & $16.48 * * *$ & $9.00 * * *$ \\
\hline $\begin{array}{l}\text { Wald test on joint significance of excluded } \\
\text { instruments: } \chi^{2}(3) \text { test in first stage } \\
\text { regression }\end{array}$ & & & & $47.81 * * *$ & $35.87 * * *$ & $35.22 * * *$ \\
\hline Log-Likelihood & $-2,324.91$ & $-2,381.90$ & $-2,326.70$ & $-6,177.17$ & $-6,255.56$ & $-6,183.28$ \\
\hline
\end{tabular}

Notes: Standard errors in parentheses are clustered to allow for correlations within regions; *** (**,*) indicate a significance level of $1 \%(5 \%, 10 \%)$,

${ }^{+}$INNOINT is instrumented with three dummy variables indicating the receipt of innovation subsidies at the firm level by origin: 1) Flemish government, 2) national government, 3) European Union.

The heteroscedasticity term includes the eight industry dummies and four size class dummies based on firms' employment in all regressions. Note that the test on heteroscedasticity in the IV Tobits refers to heteroscedasticity in both estimated equations, the NEWSALES and the INNOINT equation, simultaneously. 
Table 3: Heteroscedastic Tobit and IV Tobit on NEWMARKET (1,265 observations)

\begin{tabular}{|c|c|c|c|c|c|c|}
\hline \multirow[b]{2}{*}{ Variable } & \multicolumn{3}{|c|}{ Heteroscedastic Tobit } & \multicolumn{3}{|c|}{ Heteroscedastic IV Tobit $^{+}$} \\
\hline & Full Model & $\begin{array}{c}\text { Regional Indicators } \\
\text { only }\end{array}$ & Survey Factors only & Full Model & $\begin{array}{c}\text { Regional } \\
\text { Indicators only }\end{array}$ & Survey Factors only \\
\hline \multirow[t]{2}{*}{${I N N O I N T_{2004}}$} & $0.939 * * *$ & $1.099^{* * *}$ & $0.943 * * *$ & $2.831 * * *$ & $3.102 * * *$ & $2.860 * * *$ \\
\hline & $(0.166)$ & $(0.181)$ & $(0.165)$ & $(0.664)$ & $(0.636)$ & $(0.646)$ \\
\hline \multirow[t]{2}{*}{$\ln (E M P)_{2002}$} & $2.877 * *$ & $2.735 * *$ & $2.610 * *$ & $2.333 * *$ & $2.072 * *$ & $2.148 * *$ \\
\hline & $(1.158)$ & $(1.331)$ & $(1.193)$ & $(1.055)$ & $(1.039)$ & $(1.072)$ \\
\hline \multirow[t]{2}{*}{$K_{A P I N T} 2002$} & 0.015 & 0.023 & 0.016 & 0.010 & 0.014 & 0.009 \\
\hline & $(0.016)$ & $(0.019)$ & $(0.016)$ & $(0.016)$ & $(0.017)$ & $(0.016)$ \\
\hline \multirow[t]{2}{*}{$A G E_{2004}$} & 0.744 & 1.525 & 0.916 & 1.057 & 1.834 & 1.138 \\
\hline & $(1.284)$ & $(1.287)$ & $(1.304)$ & $(1.363)$ & $(1.331)$ & $(1.388)$ \\
\hline \multirow[t]{2}{*}{$G_{R O U P} 2004$} & 3.126 & $4.912 * *$ & 3.318 & 2.732 & $4.067 * *$ & 2.994 \\
\hline & $(1.994)$ & $(2.178)$ & $(2.131)$ & $(1.984)$ & $(2.015)$ & $(2.122)$ \\
\hline \multicolumn{7}{|c|}{ Regional Indicators: } \\
\hline \multirow[t]{2}{*}{$I^{N D E M P}{ }_{1994-2001}$} & 0.286 & 0.280 & & 0.461 & 0.393 & \\
\hline & $(0.360)$ & $(0.345)$ & & $(0.344)$ & $(0.351)$ & \\
\hline \multirow[t]{2}{*}{ DIVERS $_{1994-2001}$} & -46.411 & -40.166 & & -21.455 & -9.127 & \\
\hline & $(35.289)$ & $(35.658)$ & & $(34.210)$ & $(34.412)$ & \\
\hline \multirow[t]{2}{*}{ INNOREG $G_{2000}$} & $63.138 * * *$ & $65.705^{* * *}$ & & $60.482 * *$ & $57.673 * *$ & \\
\hline & $(24.192)$ & $(22.723)$ & & $(23.615)$ & $(22.727)$ & \\
\hline \multirow[t]{2}{*}{ COREG $_{2000}$} & -11.644 & -13.647 & & -11.391 & -11.788 & \\
\hline & (13.168) & (11.624) & & (13.084) & $(10.985)$ & \\
\hline \multirow[t]{2}{*}{ UNICLOSE } & -3.709 & -4.756 & & -3.918 & $-5.555 *$ & \\
\hline & $(3.181)$ & $(3.612)$ & & $(3.612)$ & $(3.276)$ & \\
\hline \multirow[t]{2}{*}{$R E G S U B S_{1999-2001}$} & 4.201 & 7.587 & & -0.153 & 9.238 & \\
\hline & $(32.985)$ & $(53.388)$ & & $(29.482)$ & $(30.914)$ & \\
\hline
\end{tabular}


Table 3 continued

\begin{tabular}{|c|c|c|c|c|c|c|}
\hline \multicolumn{7}{|l|}{ Survey Indicators: } \\
\hline \multirow[t]{2}{*}{ SKILL } & $10.370 * * *$ & & $10.104 * * *$ & $7.789 * * *$ & & $7.397 * * *$ \\
\hline & $(1.961)$ & & $(2.039)$ & $(2.288)$ & & $(2.278)$ \\
\hline \multirow[t]{2}{*}{$U N I$} & 5.220 & & 5.329 & 0.702 & & 0.697 \\
\hline & $(3.277)$ & & $(3.394)$ & $(3.621)$ & & $(3.932)$ \\
\hline \multirow[t]{2}{*}{ SUPPLY } & $10.071 * * *$ & & $10.568 * * *$ & $8.485 * * *$ & & $9.124 * * *$ \\
\hline & $(2.317)$ & & $(2.312)$ & $(2.739)$ & & $(2.789)$ \\
\hline \multirow[t]{2}{*}{ INFRA } & $5.721 *$ & & 6.304 & 2.805 & & 3.222 \\
\hline & $(3.156)$ & & $(3.359)^{*}$ & $(3.285)$ & & $(3.440)$ \\
\hline \multirow[t]{2}{*}{ FIS } & -2.102 & & -2.199 & -0.550 & & -1.016 \\
\hline & $(3.314)$ & & $(3.188)$ & $(3.521)$ & & $(3.387)$ \\
\hline \multirow[t]{2}{*}{$N E T$} & 1.283 & & 0.965 & -2.791 & & -3.147 \\
\hline & $(3.966)$ & & $(3.951)$ & $(4.373)$ & & $(4.490)$ \\
\hline Intercept & $\begin{array}{l}-32.328 * * * \\
(7.356)\end{array}$ & $\begin{array}{l}-30.000 * * * \\
(8.369)\end{array}$ & $\begin{array}{l}-35.025 * * * \\
(7.568)\end{array}$ & $\begin{array}{l}-36.129 * * * \\
(7.534)\end{array}$ & $\begin{array}{l}-34.507 * * * \\
(7.883)\end{array}$ & $\begin{array}{l}-36.832 * * * \\
(7.528)\end{array}$ \\
\hline $\begin{array}{l}\text { Test of joint significance of REGIONAL } \\
\text { INDICATORS; } \chi^{2}(6)\end{array}$ & 8.59 & $10.90 *$ & & 8.14 & $13.32 * *$ & \\
\hline $\begin{array}{l}\text { Test of joint significance of SURVEY } \\
\text { FACTORS; } \chi^{2}(6)\end{array}$ & $93.37 * * *$ & & $95.03 * * *$ & $30.27 * * *$ & & $32.38 * * *$ \\
\hline $\begin{array}{l}\text { Test of joint significance of SECTOR } \\
\text { dummies; } \chi^{2}(8)\end{array}$ & $28.76 * * *$ & $41.51 * * *$ & $27.83 * * *$ & $45.25 * * *$ & $50.12 * * *$ & $48.92 * * *$ \\
\hline Test on heteroskedasticity & $46.64 * * *$ & $45.28 * * *$ & $44.12 * * *$ & $2,293.25 * * *$ & $1,427.92 * * *$ & $1,494.55 * * *$ \\
\hline Wald-test of exogeneity & & & & $10.11 * * *$ & $13.18 * * *$ & $10.02 * * *$ \\
\hline $\begin{array}{l}\text { Wald test on joint significance of } \\
\text { excluded instruments: } \chi^{2}(3) \text { test in first } \\
\text { stage regression }\end{array}$ & & & & $54.54 * * *$ & $37.38 * * *$ & $36.51 * * *$ \\
\hline Log-Likelihood & $-1,647.30$ & $-1,690.19$ & $-1,651.46$ & $-5,504.29$ & $-5,569.16$ & $-5,512.54$ \\
\hline
\end{tabular}

Notes: Standard errors in parentheses are clustered to allow for correlations within regions; *** (**,*) indicate a significance level of $1 \%(5 \%, 10 \%)$,

${ }^{+}$INNOINT is instrumented with three dummy variables indicating the receipt of innovation subsidies at the firm level by origin: 1.) Flemish government, 2) national government, 3) European Union.

The heteroscedasticity term includes the eight industry dummies and four size class dummies based on firms' employment in all regressions. Note that the test on heteroscedasticity in the IV Tobits refers to heteroscedasticity in both estimated equations, the NEWSALES and the INNOINT equation, simultaneously. 


\section{CONCLUSION}

This study investigated how local milieus foster innovation success in Flemish firms. In particular, we focus on firms' new product sales and their success in introducing market novelties. We compare the impact of location factors that were indicated as important by firms themselves with measures of regional characteristics that were constructed from other data. Thus, we contrast the common practice of linking firm performance indicators to regional characteristics with survey evidence on locational factors. While the former approach assumes that location characteristics should affect all firms in the same way, the survey allows us to model how firms judge the attractiveness of locations by a heterogeneous set of criteria. It turns out that locational factors obtained from the survey, which allow the importance of regional factors to be perceived differently across firms, provide more a accurate explanation of how local milieus facilitate innovation than regional characteristics, which are assumed to affect all firms uniformly. Thus, our results illustrate that the argument that perceptions are more important for explaining organizational behavior than objective conditions (Hellriegel and Slocum 1974) also applies to how regional characteristics affect innovation success.

Further, our results show that the availability of production factors, in particular skilled labor and proximity to a network of suppliers, is crucial for regional innovation performance. Our findings are in line with other research, for example by Basevi and Ottaviano (2002), Helsley and Strange (2002), or Bacolod et al. (2007), which shows the importance of such factors for different performance indicators.

Interestingly, our robustness test using a stricter concept of innovation success, i.e. sales with market novelties excluding imitations, shows that the regions' innovation intensity matters for individual firm performance. This highlights the importance of knowledge spillovers for more radical innovation projects, which may suggest accounting for the heterogeneity of innovation activity in further research.

In conclusion, this study shows that characteristics of local milieus which are not naturally given, matter for innovation performance and thus for economic growth and future employment opportunities. For the small economic area of Flanders this suggests channels for innovation policy, especially against the background of relatively high foreign ownership in the Flemish business sector. It may be in the government's interest to design regional 
innovation policy conducive to the agglomeration of highly skilled labor and high-tech industry, to remain competitive in the process of further globalization.

In order to complement our findings, it would be interesting to analyze how policy may foster the development of regional innovative clusters. To achieve this, it would be necessary to build a panel of firms which can be traced over a certain time period so that their evolution can be linked to regional dynamics. Policy changes over time could then be linked to innovation performance due to regional factor endowments, and thus improve governmental actions fostering the development of highly innovative clusters. 


\section{REFERENCES}

Acs, Zoltan J. 2000. Regional Innovation, Knowledge, and Global Change, London: Pinter.

Acs, Zoltan J. and Attila Varga. 2002. "Geography, Endogenous Growth, and Innovation," International Regional Science Review, 25(1), 132-148.

Anselin, Luc, Attila Varga, and Zoltan J. Acs. 1997. "Local geographic spillovers between university research and high technology innovations," Journal of Urban Economics, 42(3), 422-448.

- 2000. "Geographical Spillovers and University Research: A Spatial Econometric Perspective," Growth and Change, 31(4), 501-515.

Audretsch, David B. 1998. "Agglomeration and the Location of Innovative Activity," Oxford Review of Economic Policy, 14(2), 18-29.

Audretsch, David B. and Maryann P. Feldman. 1996. "R\&D Spillovers and the Geography of Innovation and Production," The American Economic Review, 86(3), 630-640.

Audretsch, David B., Erik E. Lehmann and Susanne Warning. 2003. "University Spillovers: Strategic Location and New Firm Performance," Centre for Economic Policy Research, Discussion Paper Series No. 3837, London.

Autant-Bernard, Corinne. 2002. "The geography of knowledge spillovers and technological proximity," in M. Feldman \& N. Massard (eds.), Institutions and Systems in the Geography of Innovation, Kluwer Academic Publisher, Boston, MA.

Bacolod, Marigee, Bernardo S. Blum, and William C.Strange. 2007. "Skills in the city," working paper 2008_187, Toronto.

Baptista, Rui and Gavin Peter Swann. 1998. "Do firms in clusters innovate more?," Research Policy, 27(5), 525-540.

Basevi, Giorgio and Gianmarco I.P. Ottaviano. 2002. "The district and the global economy: Exportation versus foreign location," Journal of Regional Science, 42(1), 107-126.

Czarnitzki Dirk. 2006. Research, development and innovation in Flanders 2004, IWT Study No. 55, Brussels.

Ciccone, Antonio and Robert E. Hall. 1996. "Productivity and the density of economic activity," American Economic Review, 86(1), 54-70.

Cohen, Wesley M. and Daniel A. Levinthal. 1989. "Innovation and Learning: The Two Faces of R\&D," The Economic Journal, 99(3), 569-596.

Coucke, Kristien and Leo Sleuwaegen. (2008), "Offshoring as a survival strategy: Evidence from manufacturing firms in Belgium," Journal of International Business Studies, forthcoming.

Davelaar, Evert Jan and Peter Nijkamp. 1989. "Spatial Dispersion of Technological Innovation: A case study for the Netherlands by means of partial least squares," Journal of Regional Science, 29(3), 325-346. 
1997. Spatial Dispersion of Technological Innovation: A Review, in C.S. Bertuglia, S. Lombardo, P. Nijkamp (eds.), Innovative Behaviour in Space and Time, Springer, Berlin Heidelberg New York.

Duranton, Gilles and Diego Puga. 2001. "Nursery Cities: Urban Diversity, Process Innovation, and the Life-Cycle of Products," American Economic Review, 91(5), 14541477.

Ellison, Glenn and Edward L. Glaeser. 1999. "The geographic concentration of industry: does natural advantage explain agglomeration?", American Economic Review, 89(2), 311-316.

Essletzbichler, Jürgen and David L. Rigby. 2007. "Exploring Evolutionary Economic Geographies," PEEG Working Paper Series No. 07.02, Utrecht.

Feldman, Maryann P. 1994a. The Geography of Innovation, Kluwer Academic Publishers, Dordrecht.

- 1994b. "The university and economic development: the case of Johns Hopkins University and Baltimore," Economic Development Quarterly, 8(1), 67-76.

Feldman, Maryann P. and David B. Audretsch. 1999. "Innovation in cities: Science-based diversity, specialization and localized competition," European Economic Review, 43(2), 409-429.

Feldman, Maryann P. and Ali S. Kutay. 1997. "Innovation and Strategy in Space: Towards a New Location Theory of the Firm," in C.S. Berluglia, S. Lombardo, P. Nijkamp (eds.), Innovative Behaviour in Space and Time, Springer, Berlin Heidelberg New York.

Fischer, Manfred and Attila Varga. 2003. "Spatial Knowledge Spillovers and University Research: Evidence from Austria," Annals of Regional Science, 37(2), 303-322.

Frenkel, Amnon and Daniel Shefer. 1997. "Technological Innovation and Diffusion Models: A Review," in C.S. Berluglia, S. Lombardo, P. Nijkamp (eds.) Innovative Behaviour in Space and Time, Springer, Berlin Heidelberg New York.

Fujita, Masahisa and Jacques-François Thisse. 2000. "Cities and agglomeration," in J.-M. Huriot and J.-F. Thisse (eds.), Economics of Cities: Theoretical Perspectives, Cambridge University Press, Cambridge.

Glaeser, Edward L. 1999. "Learning in cities," Journal of Urban Economics, 46(2), 254-277.

Goorden, Lieve 2004. "Innovation Policy and Technology Assessment in Flanders," Study commissioned by the Flemish Institute for Science and Technology Assessment viWTA, STEM - Research Centre on Technology, Energy and Environment, Brussels.

Greene, William H. 2005. Econometric Analysis, $5^{\text {th }}$ edition, Prentice-Hall, New Jersey.

Grossman, Gene M. and Elhanan Helpman. 1990a. "Trade, Innovation and Growth," American Economic Review, 80(2), 86-91.

. 1990b. "Comparative Advantage and Long-Run Growth," American Economic Review, 80(4), 796-815.

1991. "Endogenous Product Cycles," Economic Journal, 101(408), 1214-1229. 
- 1994. "Endogenous Innovation in the Theory of Growth," Journal of Economic Perspectives, 8(1), 23-44.

Harhoff, Dietmar 1999. "Firm formation and regional spillovers-evidence from Germany," Economics of Innovation and New Technology, 8(1/2), 27-56.

Hassink, Robert 1993. "Regional innovation policies compared," Urban Studies, 30(6), 10091024.

Hellriegel, Don and John W. Slocum Jr. 1974. "Organizational Climate: Measures, Research and Contingencies," Academy of Management Journal, 17(2), 255-280.

Henderson, J. Vernon, Ari Kuncoro and Matt Turner. 1995. "Industrial development in cities," Journal of Political Economy, 103(5), 1067-1090.

Henderson, J. Vernon. 2003. "Marshall's scale economies," Journal of Urban Economics, $53(1), 1-28$.

Huffman, David and John M. Quigley. 2002. "The Role of the University in Attracting Hightech Entrepreneurship: A Silicon Valley Tale," Annals of Regional Science, 36(3), 403419.

Jacobs, Jane. 1969. The Economics of Cities, Vintage, New York.

Jaffe, Adam B., Manuel Trajtenberg and Rebecca Henderson. 1993. "Geographic localization of knowledge spillovers as evidenced by patent citations," Quarterly Journal of Economics, 108(3), 577-598.

Kleinknecht Alfred and Tom P. Poot. 1992. "Do regions matter for R\&D?," Regional Studies, 26(3), 221-232.

Lösch, August. 1938. "The Nature of Economic Regions," Southern Economic Journal, 5(1), 71-78.

Love, James H. and Stephen Roper. 2001a. "Outsourcing in the Innovation Process: Locational and Strategic Determinants," Papers in Regional Science, 80(3), 317-336.

- 2001b. "Location and network effects on innovation success: evidence for UK, German and Irish manufacturing plants," Research Policy, 30(4), 643-661.

Marshall, Alfred. 1920. Principles of Economics, $7^{\text {th }}$ ed. Macmillan, London.

Meester, Wilhelm J. 2000. "Locational self-preference of firms," Paper for the $40^{\text {th }}$ European Congress of the Regional Science Association, Barcelona.

North, Douglass C. 1955. "Location Theory and Regional Economic Growth," The Journal of Political Economy, 63(3), 243-258.

OECD/EUROSTAT 2005. Oslo Manual, $3^{\text {rd }}$ edition, OECD, Paris.

OECD 2005. "Trends and Recent Developments in Foreign Direct Investment," in International Investment Perspectives, Chapter 1, Paris.

Ottaviano, Gianmarco I.P. and Diego Puga. 1998. "Agglomeration in the Global Economy: A Survey of the 'New Economic Geography'," The World Economy, 21(6), 707-731.

Porter, Michael E. 1998. "Clusters and the New Economics of Competition," Harvard Business Review, November-December, 1-14. 
Richardson, Harry W. 1974. "Agglomeration Potential: A Generalization of the Income Potential Concept," Journal of Regional Science, 14(3), 325-336.

Rigby, David L. and Jürgen Essletzbichler. 2002. "Agglomeration economies and productivity differences in U.S. Cities," Journal of Economic Geography, 2(4), 407-432.

Roper, Stephen, James H. Love, Brian Ashcroft and Steward Dunlop. 2000. "Industry and location effects on UK plants' innovation propensity," The Annals of Regional Science, 34(4), 489-502.

Rosenthal, Stuart and William C. Strange. 2003a. "Geography, Industrial Organization, and Agglomeration," CPR Working Paper No. 56, New York.

- 2003b. "Evidence on the Nature and Sources of Agglomeration Economics," in V. Henderson and J.F. Thisse (eds.), Handbook of Regional and Urban Economics Volume 4, North Holland.

- 2001. The Determinants of Agglomeration, Journal of Urban Economics, 50(2), 191-229.

Helsley, Robert W. and William C. Strange. 2002. "Innovation and Input Sharing," Journal of Urban Economics, 51(1), 25-45.

Shefer, Daniel. 1973. "Localization Economies in SMSs: A Production Function Analysis," Journal of Regional Science, 13(1), 55-64.

Shefer, Daniel and Amnon Frenkel. 1998. "Local milieu and innovations: Some empirical results," The Annals of Regional Science, 32(1), 185-200.

Smits, Elke, Bart Van Looy, Koenraad Debackere, Elisabeth Monard, Vincent Thoen, Elie Ratinckx, Danielle Raspoet, Karel Vinck. 2006. "Regional Technology Foresight Flanders 2015: Expert validated priority setting on technology and innovation within 6 strategic clusters in Flanders (Belgium)," Seville.

Strange, William, Walid Hejazi, and Jianmin Tang. 2006. "The Uncertain City: Competitive Instability, Skills, Innovation, and the Strategy of Agglomeration," Journal of Urban Economics, 59(3), 331-351.

Stuart, Toby and Olav Sorenson. 2003. "The geography of opportunity: spatial heterogeneity in founding rates and the performance of biotechnology firms," Research Policy, 32(2), 229-253.

Sveikauskas, Leo A. 1975. "The Productivity of Cities," Quarterly Journal of Economics, 89(3), 393-413.

Varga, Attila. 2000. "Local academic knowledge spillovers and the concentration of economic activity," Journal of Regional Science, 40(2), 289-309.

- 2001. "Universities and regional economic development: Does agglomeration matter?," in B. Johansson, C. Karlsson, R. Stough (eds,), Theories of Endogenous Regional Growth - Lessons for Regional Policies, Springer, Berlin.

Von Hippel, Eric. 1994. "Sticky Information and the Locus of Problem Solving: Implications for Innovation," Management Science, 40(4), 429-439. 
Zucker, Lynne G., Michael R. Darby, and Jeff S. Armstrong. 1998. "Geographically Localized Knowledge: Spillovers and Markets," Economic Inquiry, 36(1), 65-86. 


\section{APPENDIX}

Table A1: Industry description (full sample, 1,265 obs.)

\begin{tabular}{cllc} 
Number & Industry & Industry definition according to NACE sectors & Obs. \\
\hline 1 & Textiles, Paper, Wood & $17,18,19,20,21,22$ & 123 \\
3 & Chemical, Plastics & $23,24,25$ & 78 \\
4 & Metal & 27,28 \\
6 & Electronics, Machinery, Vehicles & $29,34,35,30,31,32,33$ & 100 \\
7 & Other Industries & $1,14,15,16,26,36,37,40,41,45$ & 152 \\
8 & Trade & $50,51,52$ & 228 \\
9 & Transport & $60,61,62,63,64$ & 233 \\
10 & Information Services & $72,73,74.2,74.3$ & 118 \\
11 & Other Services & $65,66,67,74($ except 74.2, 74.3), 85, 90 & 105 \\
\hline & & 128 \\
\hline
\end{tabular}


Table A2: Correlation matrix (full sample, 1,265 observations)

\begin{tabular}{|c|c|c|c|c|c|c|c|c|c|c|c|c|c|c|c|c|c|c|}
\hline & NEWSALES & $\ln (E M P)$ & $A G E$ & GROUP & SKILL & $U N I$ & SUPPLY & INFRA & FIS & $N E T$ & INNOINT & KAPINT & INDEMP & DIVERS & $R D R E G$ & COREG & UNICLOSE & REGSUBS \\
\hline NEWSALES & 1 & & & & & & & & & & & & & & & & & \\
\hline $\ln (E M P)$ & 0.1173 & 1 & & & & & & & & & & & & & & & & \\
\hline$A G E$ & 0.0756 & 0.2157 & 1 & & & & & & & & & & & & & & & \\
\hline GROUP & 0.1176 & 0.4415 & 0.0100 & 1 & & & & & & & & & & & & & & \\
\hline SKILL & 0.2823 & 0.1605 & 0.0387 & 0.1428 & 1 & & & & & & & & & & & & & \\
\hline UNI & 0.1375 & 0.0573 & -0.0158 & 0.0682 & 0.2877 & 1 & & & & & & & & & & & & \\
\hline SUPPLY & 0.1744 & 0.0035 & 0.0032 & 0.0285 & 0.2205 & 0.0695 & 1 & & & & & & & & & & & \\
\hline INFRA & 0.2075 & 0.0441 & 0.0067 & 0.0414 & 0.2911 & 0.0799 & 0.3974 & 1 & & & & & & & & & & \\
\hline FIS & 0.0802 & 0.0269 & -0.0094 & 0.0337 & 0.1800 & 0.0770 & 0.2139 & 0.3149 & 1 & & & & & & & & & \\
\hline$N E T$ & 0.1148 & 0.0809 & -0.0252 & 0.0249 & 0.1436 & 0.2012 & 0.1614 & 0.1058 & 0.1896 & 1 & & & & & & & & \\
\hline INNOINT & 0.3119 & -0.0309 & -0.0791 & 0.0048 & 0.2109 & 0.2258 & 0.1163 & 0.1884 & 0.0713 & 0.1220 & 1 & & & & & & & \\
\hline KAPINT & 0.0761 & -0.0127 & -0.0250 & 0.0382 & -0.0083 & 0.0207 & 0.0431 & 0.0258 & 0.0035 & 0.0248 & -0.0058 & 1 & & & & & & \\
\hline INDEMP & -0.0188 & 0.0485 & -0.0033 & 0.1138 & -0.0208 & -0.0350 & -0.0287 & -0.0338 & -0.0268 & 0.0002 & -0.0875 & -0.0715 & 1 & & & & & \\
\hline DIVERS & -0.0275 & 0.0325 & 0.0341 & 0.0666 & -0.0131 & 0.0189 & 0.0137 & -0.0366 & -0.0485 & 0.0172 & -0.0930 & -0.0604 & 0.1513 & 1 & & & & \\
\hline$R D R E G$ & 0.0431 & 0.0057 & -0.0162 & 0.0736 & 0.0329 & 0.0620 & 0.0238 & 0.0576 & 0.0130 & 0.0103 & 0.0522 & -0.0310 & -0.0293 & 0.0044 & 1 & & & \\
\hline COREG & 0.0682 & 0.0481 & -0.0216 & 0.0752 & 0.0632 & 0.0702 & -0.0105 & 0.0399 & 0.0296 & 0.0594 & 0.1012 & 0.0040 & -0.0723 & -0.2817 & 0.2860 & 1 & & \\
\hline UNICLOSE & 0.0518 & 0.0348 & 0.0135 & 0.0789 & 0.0463 & 0.0117 & -0.0197 & -0.0090 & 0.0190 & -0.0040 & 0.0319 & -0.0094 & 0.2998 & -0.0780 & 0.2581 & 0.2733 & 1 & \\
\hline REGSUBS & 0.0419 & 0.0600 & 0.0368 & 0.1606 & 0.0523 & 0.0252 & -0.0090 & -0.0156 & 0.0149 & -0.0036 & 0.0271 & -0.0147 & 0.4052 & -0.0350 & 0.2523 & 0.3056 & 0.7305 & 5 \\
\hline
\end{tabular}


Table A3: Description of Districts and Regions within Flanders

\begin{tabular}{|c|c|c|c|c|c|c|c|c|c|c|c|}
\hline $\begin{array}{l}\text { 2-digit zip } \\
\text { code }\end{array}$ & $\begin{array}{l}\text { \# of firms } \\
\text { in our } \\
\text { sample, 2- } \\
\text { digit level }\end{array}$ & $\%$ & $\begin{array}{c}\text { 1-digit zip code } \\
\text { level }\end{array}$ & name of province & $\begin{array}{l}\text { aggr. \# of firms } \\
\text { in sample per } \\
\text { one digit zip } \\
\text { code level }\end{array}$ & $\%$ & $\begin{array}{c}\text { size by } \\
\text { population }\end{array}$ & size in $\mathbf{k m}^{2}$ & population density & $\begin{array}{l}\text { University } \\
\text { presence }\end{array}$ & $\begin{array}{l}\text { Universities' 2- } \\
\text { digit zip code }\end{array}$ \\
\hline 15 & 2 & 0.16 & \multirow{5}{*}{1} & \multirow{5}{*}{ Flemish-Brabant } & \multirow{5}{*}{114} & \multirow{5}{*}{0.09} & \multirow{5}{*}{820,272} & \multirow{5}{*}{2,422} & \multirow{5}{*}{339} & \multirow{5}{*}{$\begin{array}{l}\text { KU Brussels } \\
\text { FU Brussels }\end{array}$} & \multirow{5}{*}{10} \\
\hline 16 & 10 & 0.79 & & & & & & & & & \\
\hline 17 & 38 & 3 & & & & & & & & & \\
\hline 18 & 30 & 2.37 & & & & & & & & & \\
\hline 19 & 34 & 2.69 & & & & & & & & & \\
\hline 20 & 70 & 5.53 & \multirow{9}{*}{2} & \multirow{9}{*}{ Antwerp } & \multirow{9}{*}{380} & \multirow{9}{*}{0.30} & \multirow{9}{*}{$1,694,475$} & \multirow{9}{*}{2,908} & \multirow{9}{*}{583} & \multirow{9}{*}{ U Antwerp } & \multirow{9}{*}{20} \\
\hline 21 & 31 & 2.45 & & & & & & & & & \\
\hline 22 & 36 & 2.85 & & & & & & & & & \\
\hline 23 & 56 & 4.43 & & & & & & & & & \\
\hline 24 & 21 & 1.66 & & & & & & & & & \\
\hline 25 & 30 & 2.37 & & & & & & & & & \\
\hline 26 & 44 & 3.48 & & & & & & & & & \\
\hline 28 & 67 & 5.3 & & & & & & & & & \\
\hline 29 & 25 & 1.98 & & & & & & & & & \\
\hline 30 & 36 & 2.85 & \multirow{10}{*}{3} & \multirow{10}{*}{$\begin{array}{l}\text { Flemish-Brabant- } \\
\text { Limburg }\end{array}$} & \multirow{10}{*}{230} & \multirow{10}{*}{0.18} & \multirow{10}{*}{$1,052,467$} & \multirow{10}{*}{2,106} & \multirow{10}{*}{500} & \multirow{5}{*}{ KU Leuven } & \multirow{5}{*}{30} \\
\hline 31 & 6 & 0.47 & & & & & & & & & \\
\hline 32 & 9 & 0.71 & & & & & & & & & \\
\hline 33 & 9 & 0.71 & & & & & & & & & \\
\hline 34 & 2 & 0.16 & & & & & & & & & \\
\hline 35 & 66 & 5.22 & & & & & & & & \multirow{5}{*}{ U Hasselt } & \multirow{5}{*}{35} \\
\hline 36 & 48 & 3.79 & & & & & & & & & \\
\hline 37 & 12 & 0.95 & & & & & & & & & \\
\hline 38 & 10 & 0.79 & & & & & & & & & \\
\hline 39 & 32 & 2.53 & & & & & & & & & \\
\hline
\end{tabular}


Table A3 continued

\begin{tabular}{|c|c|c|c|c|c|c|c|c|c|c|c|}
\hline 80 & 26 & 2.06 & \multirow{9}{*}{4} & \multirow{9}{*}{ West Flanders } & \multirow{9}{*}{274} & \multirow{9}{*}{0.22} & \multirow{9}{*}{$1,130,040$} & \multirow{9}{*}{3,125} & \multirow{9}{*}{362} & \multirow{9}{*}{$\begin{array}{l}\text { KUL Campus } \\
\text { Kortirjk }\end{array}$} & \multirow{9}{*}{85} \\
\hline 82 & 10 & 0.79 & & & & & & & & & \\
\hline 83 & 8 & 0.63 & & & & & & & & & \\
\hline 84 & 13 & 1.03 & & & & & & & & & \\
\hline 85 & 66 & 5.22 & & & & & & & & & \\
\hline 86 & 21 & 1.66 & & & & & & & & & \\
\hline 87 & 46 & 3.64 & & & & & & & & & \\
\hline 88 & 58 & 4.58 & & & & & & & & & \\
\hline 89 & 26 & 2.06 & & & & & & & & & \\
\hline 90 & 66 & 5.22 & \multirow{10}{*}{5} & \multirow{10}{*}{ East Flanders } & \multirow{10}{*}{267} & \multirow{10}{*}{0.21} & \multirow{10}{*}{$1,389,199$} & \multirow{10}{*}{2,991} & \multirow{10}{*}{464} & \multirow{10}{*}{ U Ghent } & \multirow{10}{*}{9} \\
\hline 91 & 60 & 4.74 & & & & & & & & & \\
\hline 92 & 33 & 2.61 & & & & & & & & & \\
\hline 93 & 13 & 1.03 & & & & & & & & & \\
\hline 94 & 11 & 0.87 & & & & & & & & & \\
\hline 95 & 2 & 0.16 & & & & & & & & & \\
\hline 96 & 8 & 0.63 & & & & & & & & & \\
\hline 97 & 9 & 0.71 & & & & & & & & & \\
\hline 98 & 46 & 3.64 & & & & & & & & & \\
\hline \multirow{2}{*}{99} & 19 & 1.5 & & & & & & & & & \\
\hline & & & & & & & & (5221/sq mi) & (1166/sq mi) & & \\
\hline Total & 1,265 & 100 & & & 1,265 & 1.00 & $6,086,453$ & 13,552 & 449 & & \\
\hline
\end{tabular}

